\title{
Early diagnosis of HIV-I infection in newborns, in the context of prevention of mother-to-child transmission with HAART (Perinatal Cohort ANRS Co 0I)
}

\author{
Véronique Avettand-Fénoël*1, Marie-Laure Chaix ${ }^{1}$, Stéphane Blanche ${ }^{1}$, \\ Marianne Burgard ${ }^{1}$, Josiane Warszawski ${ }^{2}$ and Christine Rouzioux ${ }^{1}$
}

Address: ${ }^{1}$ AP-HP, CHU Necker, EA 3620 Université Paris-Descartes, France and ${ }^{2}$ INSERM U822, Le Kremlin-Bicêtre, France

* Corresponding author

from Fourth Dominique Dormont International Conference. Host-Pathogen Interactions in Chronic Infections

Paris, France. 13-15 December 2007

Published: 9 April 2008

Retrovirology 2008, 5(SuppI I):O24 doi:I0.I I86/I742-4690-5-SI-O24

This abstract is available from: http://www.retrovirology.com/content/5/SI/O24

(C) 2008 Avettand-Fénoël et al.; licensee BioMed Central Ltd.

\section{Background}

In 2007 , less than $1 \%$ of the children born in France to HIV1 positive mothers are infected, as preventive HAART is used. A high HIV-1 genetic diversity is observed, with nearly $60 \%$ of non-B subtypes, especially among women of African origin. The objective of this study was to evaluate new molecular technologies developed for HIV-1 diagnosis in babies, using HIV-DNA and HIV-RNA detection in babies' blood samples.

\section{Material and methods}

All infants born between May 2005 and April 2007, with samples sent to Necker's Virology Laboratory, were included in this study. Early diagnosis was based on viral detection on samples taken in the first days of life, at 1, 3 and 6 months. A new protocol using Real Time PCR technology (LTR) was developed to facilitate HIV diagnosis on whole blood that used HIV-DNA quantification in cells (ANRS AC 11/12) (1 1 g total DNA per amplification; detection cut-off value $1.6 \mathrm{log}$ HIVcopies/106 leukocytes). HIVRNA was quantified in plasma (Roche Cobas Amplicor and Cobas Taqman).

\section{Results}

1135 infants were included in this sub-study of the National EPF cohort, with 3133 samples received in the Laboratory during the study period. The specificity of HIVDNA and HIV-RNA real time PCR assays was estimated at $100 \%$ and $98 \%$ respectively; 1126 children were not infected, nine were infected as they presented with positive results on two consecutive samples; five of them were in utero infected ( $1^{\text {st }}$ sample at birth: median HIVDNA=2.2log copies $/ 10^{6}$ leukocytes $[\mathrm{min}<1.6 \log$, max:3.7logl, median HIV-RNA=3.5log copies $/ \mathrm{mL}$ [min:1.8log, max:4.3log]), while four infants were intrapartum infected: the first sample negative with both techniques and the second one positive: median HIVDNA=2.85log [min:2.1log, max:3.7log], median HIVRNA=5.1log [min:1.6log, max:6.4log].

Six patients had low viral levels ( 8 samples with HIVDNA<2.5log; and 8 samples with HIV-RNA<4.0log). Lastly, two infants had discordant results, one with HIV-DNA negative and HIV-RNA at $1.8 \mathrm{log}$; inversely, the $2^{\text {nd }}$ infant with HIV-RNA negative, while HIV-DNA was at $2.0 \mathrm{log}$, underlying the necessity to perform both assays in the context of preventive HAART.

\section{Conclusions}

Despite HAART, few cases of infection are still occurring in newborns of northern countries. The HIV-1 primary infection occurs in infants under antiretroviral pressure, reducing viral replication's level, so making the diagnosis more difficult than previously. Our results show that, in the context of preventive HAART, very sensitive and specific techniques are necessary to detect very low viral levels before 60 days of life, both in plasma and PBMC of HIV-1 infected infants.

\section{Acknowledgements}

This work is presented on behalf of the Co 0 I ANRS Cohort Study Group. 